\title{
Muusikaüliõpilaste refleksiooni toetamine pilliõppes
}

\author{
Tuulike Kivestu $^{\text {acl }}$, Äli Leijen ${ }^{\text {ab }}$, Kadri Steinbach ${ }^{\text {ac }}$ \\ a Tartu Ülikooli Viljandi kultuuriakadeemia \\ b Tartu Ülikooli haridusteaduste instituut \\ ${ }^{c}$ Eesti Muusika-ja Teatriakadeemia
}

\begin{abstract}
Annotatsioon
Tänapäevase muusikahariduse valdkonnas rõhutatakse aktiivõppe, sh refleksiooni olulisust. Sellest hoolimata puudub erimetoodika, mis toetaks õppijate refleksiooni pilliõppes. Selle uurimuse tarbeks korraldati ühe Eesti kõrgkooli muusikaõppe üliõpilaste $(N=11)$ hulgas ekspertide valideeritud refleksiooni toetamise mudeli prooviuuring. Mudel koosnes neljast tsüklist ja baseerus refleksiooni põhiprotsesside (kirjeldamise, hindamise, suhestumise ja refleksiooniprotsessi reflekteerimise) toetamisel. Uurimuse eesmärk oli selgitada välja, millised on muusikaõppe üliõpilaste kogemused refleksioonimudeli rakendamisel ja kuivõrd kasulikuks nad hindavad rakendatud refleksiooniülesandeid pillimänguoskuste arendamise seisukohalt. Üliõpilaste kogemuste ja hinnangute kohta koguti andmeid fookusrühma intervjuudega. Rakendatud refleksiooni toetamise mudeli puhul väärtustasid üliõpilased kõrvaltvaataja positsiooni võimaldamist, üksikasjade märkamist ja mitmekülgse tagasiside saamist kaasüliõpilastelt. Uurimistulemuste põhjal arendati mudelit edasi, et see toetaks tõhusamalt üliõpilaste refleksiooni pilliõppes ning aitaks kaasa individuaalse erialase arengu kavandamisele.
\end{abstract}

Võtmesõnad: refleksioon, muusikaharidus, pilliõpe, konstruktivism

\section{Sissejuhatus}

Aktiivõppe meetodite kasutamine on tänapäevase hariduse, sealhulgas muusikahariduse lahutamatu osa (vt nt Brown, 2008; Kährik, Leijen, \& Kivestu, 2012; Scott, 2010, 2011). Aktiivõpe seostub laiemas haridusteaduslikus kontekstis konstruktivistliku õpiteooriaga. Konstruktivismi järgi

1 Tartu Ülikooli Viljandi kultuuriakadeemia, Posti 1, 71004 Viljandi; tuulike.kivestu@ut.ee 
loob õpilane uue teadmise analüüsimise, probleemide lahendamise ning küsimustele vastuste otsimise käigus. Konstruktivismist eristatakse sageli sotsiaalkonstruktivismi, kus rõhutatakse teadmiste omandamise sotsiaalset aspekti ning suhestumist teistega. Siiski ei ole need teineteisele vastanduvad mõisted, vaid viitavad teadmiste omandamise meetodile ning esinevad sageli ka korraga, eriti muusikaõppes (Scott, 2010). Seega konstruktivistlikust vaatenurgast ei kujuta teadmised endast abstraktset hulka, mida õpilane endasse ammutab, vaid teadmine konstrueeritakse olemasoleva ja uue teadmise sünteesimisel (Webster, 2011). Olulised märksõnad sellise õpiprotsessi juures on eneseregulatsioon, enesehindamine ning õpiprotsessi reflekteerimine (Zimmerman, 1998). Nende protsesside kaudu laiendavad õpilased oma seniseid teadmisi ja kujunevad iseseisvateks muusikuteks, kes osalevad oma töös lauljate, instrumentalistide, heliloojate, improviseerijate ja kuulajatena. Selline käsitlusviis vastandub praktikale, kus õpilased osalevad küll aktiivselt praktilistes tegevustes, kuid pööravad vähem tähelepanu sellele, kuidas ülesandeid lahendada, ning nende teadlikkus oma tegevusest on piiratud (Scott, 2011). See tähendab, et praktiliste ülesannete lahendamise kõrval tuleks üliõpilasi julgustada oma tegevust reflekteerima, et saada teadlikuks oma tegevusest, mõtestada ning juhtida õppimist (vt nt Leijen, Lam, Wildschut, \& Simons, 2009a; Leijen, Valtna, Leijen, \& Pedaste, 2012; Sööt \& Leijen, 2012). Biggs (1987) viitab, et üliõpilased, kes on suutelised vahendama ja reflekteerima oma õpiprotsessi, on sageli aktiivsemad ja keskendunumad probleemilahendajad kui need õpilased, kes ootavad õpetajalt ainuõigeid vastuseid. Muusikahariduses tähendab konstruktivistliku õpiteooria rakendamine sageli, et peale tavapärase ja väga traditsioonilise õpetaja-õpilase hierarhilise suhte ning osalemise muusikategemises on ka siin võimalik õpilasel konstruktivistlikult õppeprotsessist osa võtta, esitades küsimusi ning analüüsides ja lahendades muusikaõppe käigus tekkinud probleeme (Scott, 2010).

Eeltoodust hoolimata on viimaste aastate kasvav huvi aktiivõppe meetodite ning üliõpilaste refleksiooni toetamise vastu kajastunud pilliõppes vaid vähesel määral (vt nt Draper, 2007; Kivestu \& Leijen, 2014). Pilliõppe tõhustamise strateegiaid käsitledes osutab Nielsen (2001), et väga sageli sisaldavad pilliõpingud mõnda eneseregulatsiooni meetodit, kuid õpilased ei kasuta neid teadlikult ega süsteemselt. Seetõttu vajab õppijate refleksiooni toetamine pilliõppe kontekstis otsesemat ja süstemaatilisemat tähelepanu.

Järgnevalt tutvustame uuringu teoreetilist raamistikku, sh defineerime refleksiooni mõiste, kirjeldame nelja üldist refleksiooniprotsessi, selgitame üliõpilaste jaoks kõige keerulisemaid refleksiooniprotsesside aspekte ning esitame põhimõtted, kuidas refleksiooni tõhusamalt toetada. 


\section{Refleksiooni mõiste}

Refleksiooni on sageli defineeritud kognitiivse protsessina, mille käigus õpitakse kogemusest kas üksi või koostöös teistega (nt Benammar, 2004; Dewey, 1933; Schön, 1983). Refleksioon võimaldab luua teadmist iseenda tunnetusest ning korrastada seda tunnetust. Sageli on viidatud, et refleksioon toetab sügavamat õppimist (Moon, 2004), annab võimaluse omandada komplekssemaid ja seostatumaid teadmiste struktuure ning võimaldab luua kasutatavamat ja kättesaadavamat teadmist (Billing, 2007). Refleksiooni käsitlustes eristatakse sageli kahte suunda, mis rajanevad erinevatel filosoofilistel alustel: pragmatismi ja sotsiaalkriitilist teooriat (Procee, 2006). Procee tutvustas oma artiklis ka kolmandat käsitlust, mis põhineb Kanti seisukohtadel, eelkõige tema vaadetel reflektiivsest ja deduktiivsest otsustusest. Siinses artiklis käsitleme refleksiooni pragmatistliku traditsiooni raames, mille kohaselt on refleksiooni peamine eesmärk tegevuse parandamine (improvement). Seevastu sotsiaalkriitilise teooria kohaselt oleks refleksiooni eesmärk üksikisikute ja suuremate rühmade vabastamine (emancipation) harjumuspärasest ning kantiaanlikus traditsioonis mõiste ja praktika vahel kooskõla leidmine (vt nt Leijen, 2008).

Kooskõlas eelnevaga võimaldab refleksioon pilliõppes tõhustada instrumendi harjutamist, sest reflekteerimine aitab mõtestada oma nõrku külgi ning jõuda lahenduseni, kuidas neid parandada (Parncutt, 2007). Samuti aitab eneseregulatsioonimeetodite (sh refleksiooni) kasutamine kaasa sellise iseseisva õppija kujunemisele, kes on suuteline oma õpiprotsessi juhtima (Zimmerman, 2002) ning võtma selle eest vastutuse (Latukefu, 2009).

Dewey (1933) reflekteeriva mõtlemise teoorias on tegevus ja mõtlemine omavahel põimunud ja toimuvad korraga. Hilisema eristuse kogemuse ja refleksiooni vahel tegi Schön (1983). Ta avastas, et professionaalid olid hõlmatud kahte tüüpi refleksiooni: tegevusaegsesse ja -järgsesse refleksiooni. Mõlemas tüübis on kogemus ja refleksioon erinevalt seotud. Samuti nõuavad need refleksioonitüübid erinevat kogemuste pagasit. Meijer (2013) toob õpetajate näitel esile kogenumate praktikute suutlikkuse reflekteerida tegevuse käigus, samal ajal kui algajad pole selleks sageli suutelised ning on seotud ainult teist tüüpi, tegevusjärgse refleksiooniga. Põhjuseks on vähene kogemus oma teadmiste sünteesimisel ning kiire reaktsiooni puudumine.

Kooskõlas pragmatistliku traditsiooniga viitab Nielsen (2001) ka refleksiooni tsüklilisele iseloomule, seda eriti muusika, sh pilliõpingute kontekstis see moodustab ühe osa üldisest õpiprotsessist, mille juurde võivad kuuluda ka muud teadliku õppimise meetodid (eesmärkide seadmine, strateegiline õpiprotsessi planeerimine, eneseinstrueerimine). 


\section{Refleksiooniprotsessidega seotud raskused ja nende ületamine}

Procee (2006) järgi võib haridusteaduslikus paradigmas eristada nelja üldist refleksiooniprotsessi: 1) kogemuse kirjeldamist, 2) kogemuse hindamist, 3) suhestumist erinevate perspektiividega ja 4) refleksiooniprotsessi reflekteerimist. Järgnevalt kirjeldame raskusi, mida kogevad õppijad refleksiooniprotsesside rakendamisel, ning pakume välja võimalusi, kuidas neid ületada.

Üldiste probleemidena on üliõpilaste refleksiooni juures täheldatud, et nad kalduvad tegema pinnapealseid märkusi (nt „Mul on vaja veel palju õppida, harjutada”) ning neil esineb raskusi emotsionaalsete ja isiklike probleemidega toimetulekul (nt enda koordinatsiooni piiratud võimete teadvustamine) ning oma mõtete sõnastamisel (Leijen et al., 2009a). Varasemad uurimused (nt Korthagen \& Vasalos, 2005) näitavad, et selliste probleemide lahendamisel on osutunud kasulikuks suunavad küsimused ja refleksiooniülesannete struktureerimine.

Kirjeldusprotsessi peamised raskused hõlmavad lahknevusi teadlikustamise ja tegutsemise vahel (Argyris \& Schön, 1974). Samuti on probleemiks enda ja teiste kogemustega seonduvate üksikasjade puudulik märkamine ja raskused oma varasemate kogemuste meenutamisel (Leijen et al., 2009a). Uurimused (vt nt Kori, Pedaste, Leijen, \& Mäeots, 2014; van den Berg, 2001) näitavad, et selles protsessis saab üliõpilasi toetada, suunates neid kasutama videot, mis aitab näha ennast objektiivsest vaatenurgast, kõrvalseisjana. Oma pillimängu kirjeldamisel võiksid üliõpilastele abiks olla suunavad küsimused.

Veebil ja videol põhinevaid õppevahendeid on viimastel aastatel kasutatud palju. Professionaalses pilliõppes on enamasti tegemist passiivset õppimist soodustavate keskkondadega, kus õpilane jäljendab õpetajat, kogub infot, sekkumata ise aktiivselt protsessi. Tantsuõppe kontekstis on videopõhine refleksiooni toetamine olnud edukas ning õigustanud ennast (Leijen, Lam, Wildschut, Simons, \& Admiraal, 2009b), ka pilliõpingutele tuleb õppeprotsessi filmimine ning video hilisem analüüsimine kasuks, sest video on dokumenteeritav allikas, mida on võimalik korduvalt analüüsida. Lisaks pakub videole veebipõhise tagasiside andmine võimalust kaasata tagasisidesse peale õpetaja rohkem inimesi, nt kaasüliõpilased. On viidatud (Daniel, 2006), et see suurendab omakorda üliõpilaste ühtekuuluvustunnet, ergutab kaasavalt õppima ning võtma vastutust.

Hindamisprotsessi juures on peamine probleem hindamiskriteeriumide ebapiisavus või nende puudumine. McPherson ja Zimmerman (2011) on muusikaspetsiifilises refleksioonis nimetanud sagedase probleemina enese pinnapealset võrdlemist normidega (nt näitab teatud tehniliselt raskete 
lugudega hakkamasaamine teatud tasemele jõudmist). Lisaks on uurijad esitanud neli pilliõppega seotud hindamiskriteeriumi, mida õpilased sageli enesehindamisel kasutavad: meisterlikkus, eelnev esitus, normatiivsus ja koostöö. Meisterlikkus tähendab, et kasutatakse gradatsiooni lihtsast keerukani - sageli on nii üles ehitatud muusikakursused ja noodikogumikud. Eelnev esitus on enda praeguse soorituse võrdlemine eelneva taseme ja varasemate sooritustega. Normatiivsus tähendab enda arengu võrdlemist teiste omaga ning koostöö on oluline just rühmamängus - jälgitakse, kuidas kellegi individuaalne areng toetab kollektiivi arengut. Tulemuslikkuse seisukohalt on kõige tõhusam meisterlikkuse hindamine, mis suurendab õpilaste motivatsiooni, seevastu normatiivne hindamine toob sageli esile peamiselt negatiivseid aspekte.

Lisaks on teistes valdkondades probleemidena täheldatud, et õppejõult oodatakse paranduste tegemist ja ei olda valmis ennast ise hindama, keskendutakse peamiselt puudustele ning jäetakse tähelepanuta positiivsed aspektid, ollakse šokeeritud asjaolust, et plaanitu ei realiseerunud praktikas, ning piirdutakse üksnes kirjeldamisega (Mountford \& Rogers, 1996; Poom-Valickis \& Mathews, 2013). Et üliõpilased õpiksid oma tegevust ja muusikalist arengut ise hindama ning mitte ootama vaid õppejõudude hinnangut nende tööle, arengule ja pillimängu tasemele, on vaja välja töötada hindamiskriteeriumid ja neid kasutada. On oluline, et kõik üliõpilased tunneksid hindamiskriteeriume ning oskaksid ise oma pillimängu nendele toetudes hinnata.

Suhestumisprotsessi puhul on märgatud, et õppejõu tehtud parandusi ja ettepanekuid ei seata kahtluse alla, vaid võetakse absoluutse tõena, keskendutakse vaid õigesti tegemisele ning kogetakse raskusi alternatiivsete lahenduste leidmisel, samuti häbenetakse jagada ja esitada omi ideid ning keskendutakse teistele tagasiside andmisel vaid puudustele (Leijen et al., 2009a). Need probleemid viitavad ühelt poolt sotsiaalse suhtlemise ja grupidünaamika eripärale (Mackintosh, 1998; Wade, 1994) ning teiselt poolt võimu ja autoriteediga seotud probleemidele õppejõu ja üliõpilaste suhtluses (Leijen et al., 2009a). Viimaste leevendamiseks võiks õppeprotsessi kaasata enam kaasüliõpilasi, et pakkuda üksteisele suuremat tuge. Sotsiaalse suhtlusega seotud raskuste vältimiseks tuleks kokku leppida kommunikatsioonireeglid, sh tagasiside andmine.

Refleksiooniprotsessi reflekteerimise puhul seisneb põhiline raskus selles, et abstraktsel tasandil oma tegevuse reflekteerimine, sh oma professionaalse identiteedi üle arutlemine, võib olla keeruline (Procee, 2006). Selle toetamiseks sobivad sekundaarse refleksiooni ülesanded (vt nt Clark, 2009), mille täitmisel õppija analüüsib varasemaid esmaseid refleksioone. 
Kokkuvõtteks võib seega väita, et üliõpilaste kunstiloomingu dokumenteerimine video vahendusel, suunavad küsimused ning kaasüliõpilaste konstruktiivne tagasiside võiks toetada üliõpilaste refleksiooni pilliõpingutes. Selle põhjal töötati välja kõrgkooli pilliõppe konteksti sobiv refleksiooni toetamise mudel (vt ptk „Refleksiooniülesanded”), mille valideerisid esmalt kogenud pilliõppe õppejõud (vt Kivestu \& Leijen, 2014). Praeguses uurimuses keskendume selle mudeli esmasele rakendamisele pilliõppe üliõpilaste hulgas ning otsime vastuseid järgmistele uurimisküsimustele:

1) kuidas üldiste refleksiooniprotsesside põhjal väljatöötatud ülesanded toetavad muusikaõppe üliõpilaste hinnangul nende õpiprotsessi?

2) kuidas mõtestavad üliõpilased rakendatud refleksiooniülesannete kasulikkust oma erialase arengu seisukohalt?

Pärast vastamist nendele küsimustele esitame ka ettepanekud konkreetse refleksioonimudeli edasiarendamiseks.

\section{Metoodika}

\section{Uuritavad}

Refleksiooni toetamise mudelit rakendas üksteist üliõpilast ühe Eesti kõrgkooli muusikaosakonnast, neist kolm olid koolimuusika bakalaureuseõppe, kuus jazz-muusika rakenduskõrghariduse ja kaks pärimusmuusika rakenduskõrghariduse õppekavalt. Uuringus osalejate hulgas oli viis meest ja kuus naist vanuses 19-26 aastat. Põhierialana õppisid uuritavatest kaks saksofoni, kaks kitarri, kaks klaverit, kolm laulu, üks flööti ja üks löökpille. Uuringus osalemine oli vabatahtlik ja üliõpilastele ei pakutud selle eest mingeid hüvesid.

\section{Refleksiooniülesanded}

Refleksiooni toetamise mudel, mille olid kogenud pilliõppe õppejõud varem valideerinud (Kivestu \& Leijen, 2014), koosnes pragmatistliku traditsiooni kohaselt refleksioonifaasist ja metarefleksiooni faasist, kusjuures refleksioonifaas moodustus omakorda kolmest tsüklist (joonis 1). Igas tsüklis lasti üliõpilastel täita kirjeldamis-, hindamis- ja suhestumisülesandeid ning toetati neid protsesse. Tsükli pikkus oli kolm nädalat. Seega kestis refleksioonifaas kokku üheksa nädalat ning sellele järgnes refleksiooniprotsessi reflekteerimine ehk metarefleksioon. Kolm tsüklit kavandati mudelisse selleks, et üliõpilane ei omandaks erinevate refleksiooniülesannete täitmisel vaid ühekordset kogemust ning siseneks metarefleksiooni faasi põhjalikemate teadmistega iseendast. 


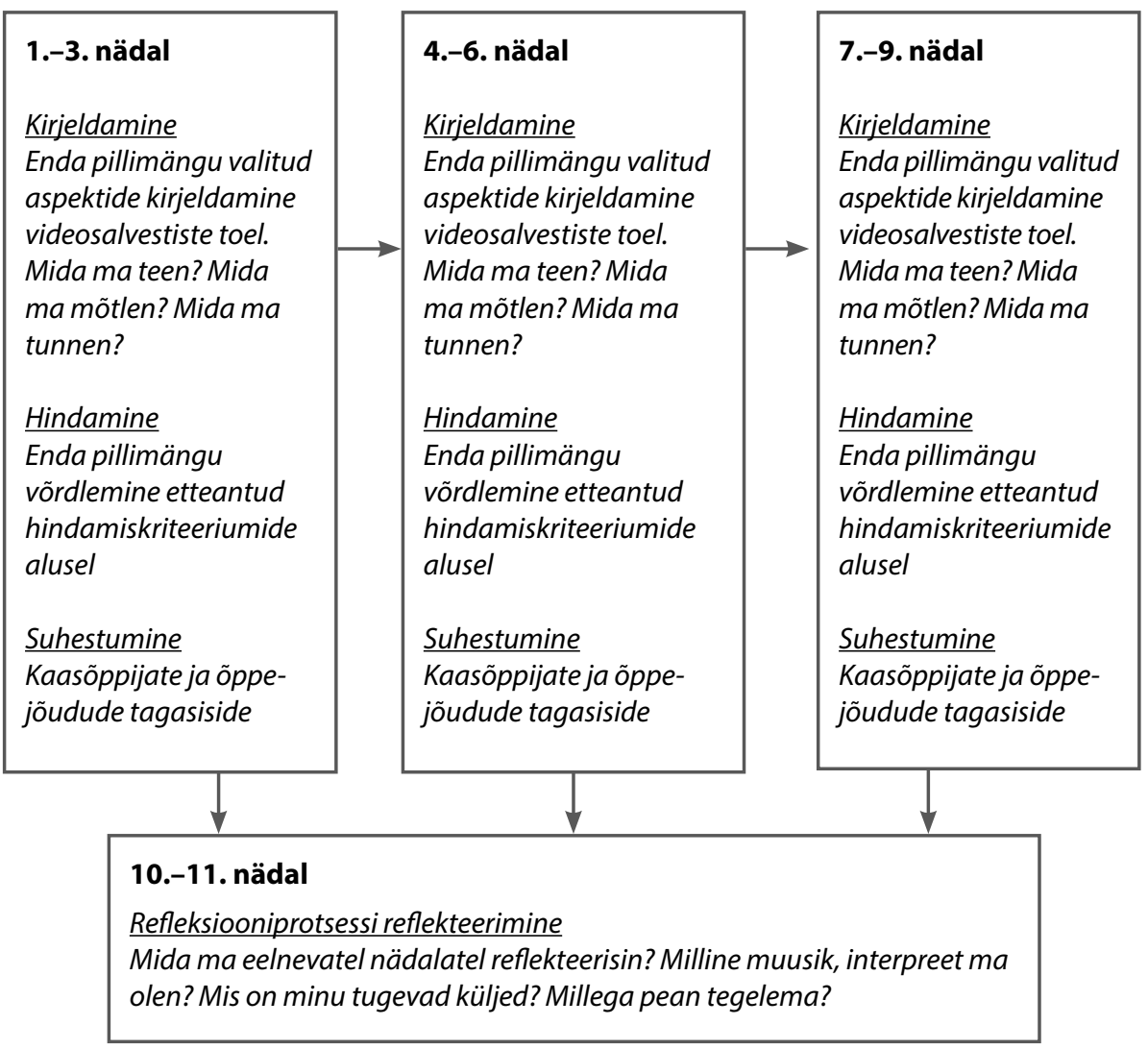

Joonis 1. Üliõpilaste refleksiooniprotsesside toetamine pilliõppe kontekstis

Järgnevalt on toodud küsimused ja ülesanded, mille eesmärk oli toetada üliõpilaste refleksiooni eri etappides.

\section{Kirjeldamine}

Kirjeldamisprotsessi toetuseks rakendati peamiselt videosalvestiste vaatamist ja kuulamist. Üliõpilase ülesanded selles etapis olid järgmised:

1) teha videosalvestis oma pillimängust (nt kontsert, ettemäng, harjutamine, pillitund);

2) valida kaks aspekti oma pillimängus (nt mängutehnika, toon, fraseerimine, improviseerimine, artistlikkus), millest üks on positiivne ja üks, mis vajab arendamist, ning keskenduda neile;

3) kirjeldada, mida ta valitud aspektide puhul salvestiselt märkab, sh vastata järgmistele küsimustele: Mida Sa kavatsesid teha? Mida Sa tegelikkuses teed? Mida Sa sealjuures mõtled? Mida Sa sealjuures tunned? 


\section{Hindamine}

Hindamisprotsessi peamised toetusaspektid olid hindamiskriteeriumide kindlaksmääramine ja nendel põhineva enesehindamise võimaldamine. Üliõpilase ülesanded selles etapis olid järgmised:

1) võrrelda videolt nähtud ning selle põhjal kirjeldatud tegelikku olukorda õppejõu antud hindamiskriteeriumidega;

2) nimetada muu hulgas positiivseid aspekte;

3) hinnata, milline on tema pillimänguoskus ja tase nende kriteeriumidega võrreldes.

\section{Suhestumine}

Suhestumisprotsessi toetamiseks tuli üliõpilasel koguda valitud pillimänguaspektide kohta tagasisidet. Selleks esitas ta kaks küsimust kaasüliõpilastele ja õppejõududele. Üliõpilastele selgitati, et tagasiside andmise peamine eesmärk on toetada kaasõppijaid, mistõttu paluti üliõpilastel tagasiside hoolikalt läbi mõelda ning see konstruktiivselt esitada. Üliõpilase ülesanded selles etapis olid järgmised:

1) sõnastada kaasüliõpilastele ja õppejõududele kaks küsimust, mille kohta ta soovib tagasisidet või soovitusi;

2) teha saadud tagasiside põhjal kokkuvõte, kas, kuivõrd ja kuidas ta saab seda arvesse võtta.

\section{Refleksiooniprotsessi reflekteerimine}

Refleksiooniprotsessi reflekteerimine on metaanalüüs, tagasivaade eelnenud üheksale nädalale ehk toimunud refleksiooni vaatlemine distantsilt. Arvestades kõiki eelneva perioodi aspekte (videote põhjal koostatud kirjeldusi, õppejõu esitatud hindamiskriteeriumide põhjal enda antud hinnangut oma pillimängule ning kaasüliõpilastelt ja õppejõult saadud tagasisidet), vastas üliõpilane järgmistele küsimustele:

1) Vaata kuut pillimängu aspekti, mida oma kirjelduses jälgisid, nimetasid. Kas mõni neist esines märkimisväärselt sagedamini? Mida see võiks tähendada?

2) Kas Sinu esitatud küsimused kaasüliõpilastele ja óppejõududele olid väga erinevad või on võimalik välja tuua sagedamini esinevaid teemasid? Milliste pillimängu aspektide (nt mängutehnika, tooni, fraseerimise, improviseerimise, artistlikkuse) kohta soovisid saada kõige rohkem tagasisidet kaasüliõpilastelt ja õppejõududelt? Mida see võiks tähendada?

3) Mis on Sinu tugevad küljed interpreedi ja muusikuna?

4) Missuguseid oskusi on veel vaja arendada, et olla parem interpreet ja muusik? Millega Sa pead veel tegelema? Mida Sa pead óppima? 
5) Kuivõrd kasulik oli refleksioon pillimängu õppimise ning isikliku muusikalise arengu seisukohalt? Mida öppisid eelnenud üheksast nädalast?

Et toetada üliõpilasi refleksiooniülesannete täitmisel, loodi Moodle’i keskkonda aine ning iga ülesande jaoks püstitati eraldi teema koos üksikasjalike juhistega. Üliõpilased esitasid kõik refleksioonimudeli ülesannete vastused Moodle'is asjaomase teema juures. Suhestumisülesande täitmiseks jagunesid üliõpilased neljaliikmelistesse rühmadesse ning tagasisidet üksteisele anti rühma sees. Rühmade moodustamisel ei peetud silmas õpitavat eriala ( $j a z z-$, pärimus- või koolimuusika) ega muusikainstrumenti.

Üliõpilaste käsutusse anti videokaamera ning muusikaosakond määras tugiisiku, kes abistas üliõpilasi tehniliste probleemide korral.

\section{Andmete kogumine ja analüüs}

Uuringus osalejatelt koguti andmeid fookusrühma intervjuudega. See meetod valiti eeskätt põhjusel, et ei tekiks erinevast võimupositsioonist tingitud konflikti uurija ja uuritavate vahel (Gibbs, 1997), sest uuringu vastutav täitja on õppejõud ja struktuuriüksuse juhataja. Lisaks võimaldas rühmaintervjuu uuringus osalenutel üksteist täiendada ning kujundada ühised seisukohad ja osutada individuaalsetele eripäradele. Sarnastel põhjustel kasutati sellist metoodikat ka varasemas uuringus, mis keskendus üliõpilaste kogemuste väljaselgitamisele refleksiooni toetamisel tantsuõppes (Leijen et al., 2009b). Uuringu raames tehti kaks intervjuud, millest esimeses osales viis, teises kuus üliõpilast. Mõlemad intervjuud kestsid umbes 1 tund ja 45 minutit, need toimusid koolikeskkonnas. Intervjueeritavaid teavitati uurimisandmete konfidentsiaalsest käsitlemisest, mille kohaselt ei avaldata andmeid uuringuga mitteseotud isikutele, sh õppejõududele, ning uurimistulemuste esitlemisel jälgitakse, et neid ei oleks võimalik seostada konkreetsete isikutega. Kõik 20 küsimust keskendusid üliõpilaste kogemustele refleksioonimudeli rakendamisel. Küsimused jagunesid omakorda kuueks teemaks: üliõpilaste kogemused erinevate refleksiooniprotsesside (kirjeldamise, hindamise, suhestumise ja refleksiooniprotsessi reflekteerimise) rakendamisel, üliõpilaste üldised muljed refleksioonimudeli rakendamisel ning üliõpilaste ettepanekud refleksioonimudeli tõhusamaks rakendamiseks. Nelja esimese teemaga seoses esitati küsimusi iga refleksiooniülesande kohta (nt Millised olid positiivsed aspektid videoga töötamisel ja kas oli ka negatiivseid aspekte? Kas opppejõududelt saadud hindamiskriteeriumid aitasid teid? Kuidas? Kuidas oli kaasüliópilastelt tagasisidet saada? Kuidas te seda kogesite?). Kahe järgmise teema puhul esitati üliõpilastele üldisemaid küsimusi refleksioonimudeli kohta (nt Kas mudeli rakendamine toetas ka pillimänguoskuste arenemist? Kas oskate midagi konkreetset välja tuua? Kuidas teile 
tundub, kas oleks kasulik, kui sellised ülesanded oleksid ülikoolis pillióppe kohustuslik osa?). Mõlemad intervjuud salvestati ja transkribeeriti täies mahus.

Andmete analüüsimiseks jaotati kogutud andmed poolstruktureeritud intervjuu järgi kategooriatese (kirjeldamine, hindamine, suhestumine ja refleksiooniprotsessi reflekteerimine, üldised muljed, soovitused). Kategooriate analüüsimiseks kasutati temaatilist analüüsi (vt Ryan \& Bernard, 2003). Temaatiline analüüs on induktiivne analüüsimeetod, mille käigus identifitseeritakse esimese sammuna avatud kodeerimise kaudu andmetes esinevad teemad.

Iga kategooria sees identifitseeriti teemad. Näiteks eristati suhestumise kategooria puhul järgmisi teemasid: üliõpilaste üldised kogemused, üliõpilaste kogemused tagasiside saamisega kaasüliõpilastelt, üliõpilaste kogemused tagasiside andmisega kaasüliõpilastele, üliõpilaste kogemused tagasisidega veebikeskkonnas, üliõpilaste kogemused tagasiside andmise ja saamisega teiste muusikastiilide ja pillide esindajatelt. Konkreetsed näited nende teemade kohta on esitatud tabelis 1 .

Tabel 1. Teemade identifitseerimine suhestumise kategoorias

\begin{tabular}{ll}
\hline Teema & Näide intervjuudest \\
\hline $\begin{array}{l}\text { Üliõpilaste üldised } \\
\text { kogemused }\end{array}$ & Ennast õpid ka mingil määral teistmoodi vaatama läbi teiste. \\
$\begin{array}{l}\text { Üliõpilaste kogemused } \\
\text { tagasiside saamisega } \\
\text { kaasüliõpilastelt }\end{array}$ & $\begin{array}{l}\text { Tagasiside oli hästi asjalik ja iga kord oli mul hea seda lugeda. } \\
\text { Ma mõtlesin, et hakkan iga kord hullult solvuma ja tüli on } \\
\text { majas. Aga lõppkokkuvõttes oli kõik väga kasulik. Olin positiiv- } \\
\text { selt üllatunud ka enda suhtes, et kui lihtne oli seda vastu võtta. }\end{array}$ \\
$\begin{array}{l}\text { Üliõpilaste kogemused } \\
\text { tagasiside andmisega } \\
\text { kaasüliõpilastele }\end{array}$ & $\begin{array}{l}\text { Hirmus oli veidi. Ma nagu ei julgenud, et kuidas ma ütlen, } \\
\text { seda-seda tuleb parandada, et äkki võtab kuidagi halvasti või } \\
\text { pahasti, aga tegelikult kui ühel hetkel sulle täpselt samamoodi } \\
\text { igasuguseid asju öeldi, siis sain aru, et tegelikult on see ju } \\
\text { ainult positiivne, kui ütlen, mida parandada. }\end{array}$ \\
\hline $\begin{array}{l}\text { Üliõpilaste kogemused } \\
\text { tagasisidega veebi- } \\
\text { keskkonnas }\end{array}$ & $\begin{array}{l}\text { Toon olulise erinevuse siiski välja - videot ma sain mitu korda } \\
\text { vaadata, aga kui ta mängib reaalselt, on see ainult ühe korra. } \\
\text { Jah, ma arvan, et tänu sellele, et sa said videot mitu korda } \\
\text { vaadata, said sa olla täpsem. }\end{array}$ \\
\hline $\begin{array}{l}\text { Üliõpilaste kogemused } \\
\text { tagasiside andmise } \\
\text { ja saamisega teiste } \\
\text { muusikastiilide ja } \\
\text { pillide esindajatelt }\end{array}$ & $\begin{array}{l}\text { Mulle meeldis see, et rühmas ei olnud oma instrumendi } \\
\text { mängijad, vaid just see inimene, kes on sul saalis. Kes ei ole } \\
\text { sama ala professionaal ja tema hinnang on minu arvates } \\
\text { kohati isegi tõesem. Tema on see inimene, kes annab sulle } \\
\text { tagasisidet, tema on see inimene, kes ostab su kontserdipileti. }\end{array}$ \\
\hline
\end{tabular}


Teise sammuna analüüsiti kogu andmehulka eristatud teemade põhjal uuesti. Siinse uurimuse tarbeks tegi andmeanalüüsi üks uurija, tulemuste usaldusväärsuse suurendamiseks arutati esimeses ja teises etapis leitud teemasid ja kategooriaid kaasuurijaga ning kasutati varem saadud tulemusi (Leijen et al., 2009) analüüsi toetavate mõistetena (sensitizing concepts).

\section{Tulemused}

\section{Kirjeldamisprotsessi käigus saadud kogemused}

Üliõpilased leidsid, et ehkki videosalvestamisega võrreldes on pillimängu õppimisel levinum viis rakendada audiosalvestamist, võimaldab filmimine pöörata tähelepanu märksa rohkematele aspektidele, nt kehahoiakule, pillimängu asendi ergonoomilisusele. Video andis võimaluse jälgida ka oma näoilmet ja kehakeelt ning aitas tudengitel hiljem meenutada oma pillimängu käigus tekkinud mõtteid ja tundeid. Kokkuvõtvalt pidasid kõik üliõpilased enese kõrvaltvaatamise kogemust väga oluliseks.

Enamik tudengitest oli juba varem teadlik oma pillimängu filmimise kasulikkusest, kuid paljud ei olnud seda ilma otsese suunamiseta ette võtnud. Umbes kolmandikul üliõpilastest oli varasem enda filmimise kogemus ning seega ei olnud see tegevus nende jaoks uudne. Neil, kel see kogemus puudus, oli esialgu end raske videolt vaadata. Ühel üliõpilasel halvenes pärast esimese videosalvestise nägemist arvamus iseendast. Järgmisi videoid vaadates suutis ta aga tasapisi leppida enda olemusega ning ta hindab saadud kogemust väga heaks. Üliõpilased mainisid ka seda, et filmimise olukord oli samaväärne esinemise omaga ning sellega kaasnes samasugune ärevus.

Uuringus osalejad toimisid erinevalt: osa muretses mulje pärast, mille nad teistele jätavad, ning filmisid igat klippi mitu korda, enne kui meelepäraseima versiooni üles laadisid, teised seevastu otsustasid, et kajastavad oma pillimängu reaalset olukorda ning esitasid kaaslastele vaatamiseks kohe esimese katse.

Ma mõtlesin selle peale, et kui ma tahan kaastudengitelt tagasisidet ja kui ma neile otse mängiks, siis nad tõenäoliselt ei annaks mulle 20 võimalust muudkui uuesti alustada. Et ma teen selle ühe, tuleb, kuidas tuleb. Mis siis, et võib vahepeal sassi minna.

Samuti toimisid tudengid erinevalt aspektide valimisel. Osa üliõpilastest valis jälgitavad aspektid alles videot vaadates, osa tegutses vastupidi: kõigepealt otsustati, mis aspektidega nad soovivad tegeleda, ning alles siis filmiti enda pillimängu. 
Üldiselt filmisid tudengid igaks etapiks uue video. Ainult üks uuringus osaleja kasutas varem filmitud lõike kontsertidest ning valis jälgitavad aspektid oma varasematest esitustest. Põhjuseks tõi ta asjaolu, et soovis tagasisidet saada ka enda artistlikkuse ja lavalise oleku kohta.

Keerulisim kirjeldamisetapi ülesanne oli uuringus osalenud üliõpilaste sõnul positiivsete aspektide leidmine enda pillimängust. Mitu vastajat möönis, et nad on kas liiga enesekriitilised või madala enesehinnanguga. Negatiivsete aspektidena videoga töötamisel mainiti võimalikke tehnilisi viperusi, mis tulenevad puudulikust kogemusest videosalvestistega töötamisel (video lõikamine, üleslaadimine jm). Samas leiti, et kaameraga on tegelikult lihtne töötada, ning lubati seda kindlasti tulevikus edasi teha.

Kokkuvõtteks võib öelda, et videoga töötamine võimaldas üliõpilastel end distantsilt vaadelda ning märgata enda juures ka selliseid aspekte, mida audiosalvestis ei võimalda.

\section{Hindamisprotsessi käigus saadud kogemused}

Oma eriala õppejõududelt hindamiskriteeriumide saamisega esines mõningaid probleeme ligi pooltel uuringus osalenud üliõpilastest. Põhjuseid oli mitu, nt õppejõu suutmatus kriteeriume sõnastada.

Õppejõud ei saanud vist hästi aru, mida ta peab tegema. Andis kirjelduse, mida jälgida. Mul oli vahepeal mõte, et hakkan ise guugeldama, mis on hindamiskriteerium. Kuidagi hästi häguseks läks. Õppejõu poolt saadud kriteeriumid olid liiga jutustavas vormis. Ei olnud väga faktipõhine.

Veel toodi probleemina esile, et kriteeriumide saamine õppejõult võttis liiga kaua aega. Teisel osal üliõpilastest laabus koostöö õppejõududega ladusalt. Näiteks tunnustati konkreetset õppejõudu.

M. andis alati väga konstruktiivse ja üheselt mõistetava kirjelduse hindamiskriteeriumile. Ja ma võtsingi neid täpselt nii, nagu ta neid kirjeldas. Me saime asjast ühtmoodi aru. Meil ei olnud mingit probleemi.

Positiivseks kogemuseks peeti võimalust arutada uuringu raames eriala õppejõuga erinevate pillimängu aspektide ja hindamiskriteeriumide teemadel, sest seeläbi saadi palju uut teada.

Hindamiskriteeriume pidasid üliõpilased pidepunktideks, mida enese analüüsimisel jälgida. Osa vastajatest leidis, et mõningad kriteeriumid olid 
neile uudsed ning nad avastasid nende abil olulisi tahke, millest nad seni teadlikud ei olnud. Teine osa leidis, et midagi uut ei olnud, küll aga oskavad õppejõud üldiselt teadaolevaid kriteeriume selgemini sõnastada. Mainiti ka seda, et ehkki õppejõult saadud kriteeriume teati ka varem, aitas see neid värskelt meelde tuletada.

Intervjuude käigus kogutud info põhjal võib öelda, et üliõpilased vajavad selgeid ja konkreetseid hindamiskriteeriume pidepunktidena, millele oma erialast arengut planeerides tugineda. Samas tuleb tõdeda, et paljude pilliõppe õppejõudude jaoks on hindamiskriteeriumide sõnastamine keeruline ülesanne.

\section{Suhestumisprotsessi käigus saadud kogemused}

Enamik vastajatest leidis, et teistelt tagasiside saamine oli väga kasulik, lausa väärtuslikem kogemus. Suur osa üliõpilastest rõhutas, et oluline oli saada tagasisidet kelleltki teiselt kui ainult oma põhipilli õpetajalt, sest ta tunneb õpilast juba liiga kaua ning võib-olla ei märka seetõttu mõningaid tahke. Positiivse kogemusena tajuti ka võimalust jälgida enda arengut, võrreldes oma hilisemaid videosalvestisi varasematega. Leiti, et arenguaspekte aitasid märgata ka rühmakaaslased, kes tegid tagasisidet andes asjakohaseid tähelepanekuid.

Mitu vastajat märkis, et nad ei olnud seni saanud õppejõududelt piisavalt detailset tagasisidet, mistõttu aitavad kaasüliõpilaste soovitused leida fookust harjutamisel. Näiteks osutati, et kaasüliõpilaste viidetele tuginedes avastati oma pillimängu vähene väljenduslikkus ning asuti teadlikult puudulikke omadusi enda juures arendama.

Olen nüüd vabam, enne oli mingi sisemine takistus. Ma ise tunnen end seesmiselt vabalt, aga see, mis välja paistab, on hoopis teine asi. Aga kui sulle öeldakse seda heatahtlikult, siis see tõstab üles ja viib edasi.

Üksmeelselt peeti oluliseks, et üliõpilasi suunati leidma kirjeldamisetapis enda juures nii positiivset kui ka negatiivset ning osalejad rakendasid automaatselt seda kogemust ka teistele tagasisidet andes. Vastajate sõnul on üsna tavapärane keskenduda sellistel puhkudel ainult negatiivsetele aspektidele ning seepärast tuleks õppida märkama positiivset. Mitu vastajat märkis, et nende eriala õppejõud juhivad tagasisidet andes nende tähelepanu vaid puudustele, mistõttu hindasid nad väga kõrgelt teistelt saadud positiivset tunnustust. Suur osa vastajatest kinnitas, et just sel põhjusel käsitlesid üliõpilased üksteiselt saadud tagasisidet edasiviivana ning nad ei tundnud 
end haavatuna ka siis, kui neid kritiseeriti ning juhiti nende tähelepanu parandamist vajavatele aspektidele. Seda, et kaasüliõpilased olid üksteise suhtes toetavad ja julgustavad, mainiti intervjuude käigus korduvalt.

Teistelt saadud positiivne tagasiside oli väga oluline eeskätt neile üliõpilastele, kelle enesehinnang on üldiselt madal ning kes tunnevad avalikult esinedes end väga ebakindlalt. Sellele probleemile osutasid peamiselt esimese kursuse tudengid. Nimetati, et uuringus osalemine aitas enesega leppida ja avastada, et ollakse tõepoolest mingites aspektides tugev ning tehakse mingeid asju hästi.

Mina ei kartnud seda, et mulle just halvasti öeldakse, aga kuna ise nagu väga hästi endast ei arva, siis oli paha ja ebamugav alguses. Aga ma sain mingit julgust sealt. Et ei olegi nii lootusetu. Ma sain hästi palju julgust üleüldse, kasvõi lavale minna. Ma lähen praegu palju julgemalt lavale, kui ma enne seda oleksin läinud.

Vaid üks uuringus osaleja nimetas, et tema rühmas esines juhtum, kus kaasüliõpilane suhtus suhestumisülesandesse liiga kergekäeliselt, mistõttu tagasiside jäi pinnapealseks ning sellest ei olnud märkimisväärset kasu. Samuti leidis üks üliõpilane, et kaaslased tundsid end justkui kohustatuna igal korral ka midagi negatiivset leidma, isegi siis, kui seda ei pruukinud olla. Nimetati $\mathrm{ka}$, et teistelt saadud tagasisidest märksa kasulikumaks peeti oskust oma ideid, vigu jm sõnastada.

Teistele tagasiside andmist pidasid üliõpilased positiivseks, kuid keeruliseks ülesandeks. Tunnistati, et hoiti end pisut tagasi, sest anti tagasisidet tuttavatele inimestele ning kardeti, et kriitika võib nende edaspidiseid suhteid mõjutada. Leiti, et kaasüliõpilaste analüüsimise kaudu õpiti ennast jälgima ning märgati enda juures asju, mida varem ei osatud tähele panna. Samuti nimetati, et tänu uuringu ülesannetele õpiti teistele tagasisidet andma.

Veebikeskkonnas video põhjal üksteisele tagasiside andmine oli üliõpilaste arvates hea kogemus. Oluliseks peeti, et salvestist on võimalik taasesitada ning seega saab tagasisidet andes olla täpsem ja märgata rohkem erinevaid aspekte kui reaalajas toimuva esituse puhul. Uuringus osalejad leidsid, et kirjaliku tagasiside andmine sunnib olema märksa põhjalikum, konkreetsem ja täpsem, sest puudub võimalus võtta appi mitteverbaalseid vahendeid, nt näoilmet, miimikat, kehakeelt. Osa vastajatest leidis, et kirjalikult on ka mugavam omi seisukohti selgitada ning vajaduse korral julgem juhtida tähelepanu negatiivsetele aspektidele. Üks üliõpilane aga arvas, et negatiivset tagasisidet on kirjalikult keerulisem anda, sest puudub võimalus 
öeldut kuidagi pehmendada. Moodle’i keskkonda pidasid kõik uuringus osalejad tuttavaks ja turvaliseks.

Negatiivsena toodi välja, et tunti puudust erialasest tagasisidest, ning leiti, et teiste stiilide ja pillide tudengid ei osanud tõenäoliselt märgata selliseid detaile, mida sama muusikastiili ja pilli esindajad oleksid suutnud märgata. Sama raskeks peeti tagasiside andmist teise pilli mängijale ning eriti siis, kui küsiti hinnanguid pillispetsiifiliste aspektide kohta. Samas tunnistasid mitmed uuritavad, et uuringus osalemine andis hariva ja silmaringi avardava kogemuse. Kuna õppekava läbimisel peaksid üliõpilased olema võimelised töötama ka ansambliõpetajatena, leiti, et on väga oluline õppida mingil määral tundma ka teiste instrumentide spetsiifikat ning harjutada nende kohta tagasiside andmist.

Osale üliõpilastest meeldis, et rühma ei moodustanud ainult sama instrumendi mängijad, sest see andis suurema võimaluse saada tagasisidet rohkematelt inimestelt - neilt, kes hiljem nende kontserte külastavad -, mistõttu pidasid nad nende tagasisidet isegi olulisemaks kui vaid sama pilli mängijate oma. Arvati, et sama eriala inimene jälgib peamiselt üksikasju ning ei suuda hinnata esitajat kui artisti tervikuna. Üliõpilased jõudsid üksmeelsele seisukohale, et rühm võiks olla moodustatud nii sama eriala kui ka teiste erialade üliõpilastest, sest siis oleks tagasiside maksimaalselt laia ampluaaga. Rühma suurust (neli liiget) peeti optimaalseks.

Kokkuvõtteks võib öelda, et tagasiside andmist ja saamist pidasid üliõpilased rakendatud mudeli kõige väärtuslikumaks osaks. Üksteisele tagasisidet andes aidati kaaslastel märgata endi juures ka positiivseid aspekte ning seega toimiti vastastikku julgustavalt ja toetavalt. Kirjaliku tagasiside andmise ülesanne õpetas üliõpilastele omi mõtteid konstruktiivselt sõnastama.

\section{Refleksiooniprotsessi reflekteerimise käigus saadud kogemused}

Üliõpilased suhtusid metarefleksiooni ülesandesse üldiselt hästi. Enese kui pillimängija ja muusiku analüüsimine oli osa üliõpilaste jaoks lihtne, teiste jaoks seevastu väga keeruline ülesanne. Üliõpilased tunnistasid, et kasutasid ennast analüüsides ka kaasüliõpilaste antud tagasisidet. Leiti, et metarefleksiooni ülesanne võimaldas analüüsida end terviklikult ning ühtlasi hinnata, kas uuringus osalemise jooksul toimus erialane areng või mitte. Mitmel juhul toodi esile, kuivõrd kasulik oli ülesanne leida enda juures positiivseid aspekte. Paljud osalejad osutasid, et selline eneseanalüüs aitab endale probleeme teadvustada.

Mitu osalejat kirjeldas, et refleksioonimudeli rakendamise algusega võrreldes tundsid nad end viimast ülesannet täites julgema, enesekindlama 
ja konkreetsemana. Leiti, et liigne enesekriitika takistab erialast arengut, kuid millegipärast valitseb muusikute seas arvamus, et mida kriitilisem enda vastu ollakse, seda parem. Sellele vastukaaluks mainiti intervjuus: „Tegelikult on see mõttetu enesepiitsutamine aga emotsionaalselt kurnav." Samuti leidsid mitu vastajat, et nad olid uuringu käigus õppinud end kõrvalt, distantsilt vaatama ning saadud kogemuse põhjal osatakse ennast muusikuna, sh enda pillimängu, hinnata neutraalsemalt ning objektiivsemalt kui varem.

Kokkuvõtvalt võib järeldada, et metarefleksiooni ülesanne aitas üliõpilastel ennast terviklikult hinnata ning teadvustada endale nii oma häid oskusi ja omadusi kui ka probleeme, millega tegeleda.

\section{Üliõpilaste üldine mulje refleksioonimudeli rakendamisest}

Kõik uuringus osalenud üliõpilased pidasid saadud kogemust positiivseks. Mitu tudengit tunnistas, et uuringus osalemine oli neile oluline ka enesedistsipliini seisukohalt, sest neid suunati tähtajaks täitma ülesandeid, mille kasulikkusest olid nad varem küll teadlikud, kuid ei tegelenud nendega. Vastajad leidsid üksmeelselt, et selline mudel aitab keskenduda pilliõpingutele ja fookustada harjutamist. Näiteks arutleti intervjuus:

See pani konkreetselt tegutsema. Muidu on ju teada küll, et pead mõtlema endale eesmärgid, et mida ma nüüd harjutan, aga see distsiplineeris ka tegema seda, mitte ei jäänud lihtsalt teadmiseks. Vanast ajast on tugevalt see harjumus lihtsalt harjutada, aga mitte alati ei kontsentreeru, mida ma tegelikult nüüd harjutan.

Vastajad jagasid arvamust, et tänu uuringu ülesannete täitmisele õpiti paremini oma aega planeerima. Lisaks leiti, et mudeli rakendamine võimaldab neil iseseisvalt jälgida oma erialast arengut. Üks üliõpilane kirjeldas seda aspekti täpsemalt.

Minu meelest oli positiivne veel seda arengut vaadata. Ma just mõtlesin, kui ma seda tegin, et see peaks olema muusikakoolides juba varajasest arengustaadiumist. Ôpetaja ütleb mulle kogu aeg, mis on valesti, aga sealt tuleb ka välja areng. Muidu on nii, et ma teen ja teen, aga ei midagi, nüüd on juba uued asjad valesti ja mida ma ikka jaman. Ja siis võrdlen esimese videoga ja vaatan, et ma olen arenenud!

Uuringus osalenud üliõpilased arvasid üksmeelselt, et kindlasti toetab refleksioonimudeli rakendamine nende pillimänguoskuste arengut. 


\section{Üliõpilaste ettepanekud refleksioonimudeli tõhusamaks rakendamiseks}

Uuringus osalejad jagasid seisukohta, et refleksiooniülesanded peaksid olema pilliõppe lahutamatu osa. Näiteks öeldi intervjuus: „Ma mõtlesin ka, et miks me seda alles nüüd teeme, see peaks olemagi kogu aeg. Mõtlesin kohe alguses, et nii hea õppevahend ju. Et muidu kuulad kogu aeg õpetaja tagasisidet, aga nüüd näed ise ka ju."

Kaasatud peaksid olema kõik eriala õppejõud, kes toetaksid ja vastutaksid süsteemi toimimise eest. Mitmel korral tõdeti, et selline väga vajalik eneseanalüüsi osa puudub praegu pilliõppes täielikult. Oluliseks peeti, et mudel annab üliõpilastele võimaluse saada regulaarset tagasisidet ka mujalt kui ainult oma eriala õppejõududelt. Leiti, et tagasiside andmisse võiks peale üliõpilaste kaasata ka teisi õppejõude.

Kõik vastajad arvasid üksmeelselt, et refleksioonitsükli kirjeldamis- ja hindamisetapid võiksid olla kavandatud ühele nädalale. Seetõttu ei järgitud mudelis esitatud juhiseid, vaid toimiti ülesannete täitmisel ikkagi oma äranägemise järgi, sest see tundus osalejatele märksa loomulikum. Intervjuudes mainisid üliõpilased seda järgmiselt.

Minu jaoks oli liiga hajutatud. Lõpuks ma laadisin ikka ühel öösel mitu ülesannet korraga.

Minu arvates võiks ka mitu asja koos olla, sest et see õppejõult kriteeriumide küsimine, see ei ole nii suur asi, et sinna peaks väga palju aega panustama. Pika ajaga võivad asjad juba meelest ära minna. Tekkis see asi, et ühte etappi, ühte tegevuste gruppi oli lihtsam teha korraga.

Siit formuleerus ka osalejate ettepanek, et edaspidi võiksid kirjeldamis- ja hindamisülesanded jääda ühte nädalasse, suhestumisetapp aga teise. Vastajad leidsid, et hindamise juures on tähtis, et esitus oleks väga värskelt meeles.

Kõigi vastajate arvates on pakutud mudeli rakendamise aeg (11 nädalat) liiga lühike, et pillimängu tehnilistes oskustes märgatavalt areneda. Mitu üliõpilast arvas, et sellisel juhul oleks tudeng pidanud keskenduma kogu uuringu vältel ühele konkreetsele tehnilisele aspektile ja tegelema sellega. Kuna neile esitatud ülesanded võimaldasid valida iga kord erinevaid aspekte, siis tehtigi seda, mistõttu ei täheldatud konkreetseid edusamme pillimängu tehniliste oskuste arengus.

Arvati, et intensiivsuselt võiksid tsüklid olla rohkem hajutatud ning neid võiks korraldada näiteks kord semestris. Ühe fookusrühma üliõpilased tegid ettepaneku, et õppeaasta jooksul võiksid kohustuslikud olla kaks refleksioonitsüklit: üks sügisel ja teine kevadel. Esimese tsükli tulemusel 
võiks üliõpilane püstitada endale eesmärgid ja ülesanded algavaks õppeaastaks, teises tsüklis saaks ta analüüsida, kuivõrd ta suutis need eesmärgid täita. Selline korraldus võimaldaks tudengil ise oma arengut süstemaatiliselt kavandada ja jälgida.

\section{Arutelu}

Siinse uurimuse tarbeks rakendati refleksiooni toetamise mudelit pilliõppe üliõpilaste hulgas. Mudel koosnes neljast tsüklist ja baseerus refleksiooni põhiprotsessidel: kirjeldamisel, hindamisel, suhestumisel ja refleksiooniprotsessi reflekteerimisel (Procee, 2006). Mudel võimaldas üliõpilastel reflekteerida oma pillimängu ja muusikuks olemist, kasutades videosalvestisi, suunavaid küsimusi (k.a õppejõudude antud hindamiskriteeriumid) ning kaasüliõpilaste konstruktiivset tagasisidet. Allpool arutleme peamiste tulemuste üle ja esitame kokkuvõtvad järeldused.

\section{Refleksiooniülesannete kasutegurid pilliõppes}

Uuring kinnitas varasemate uuringute tulemusi (vt nt Leijen et al., 2009a; Mountford \& Rogers, 1996), et üliõpilastel esineb probleeme erinevates refleksiooniprotsessides. Intervjuude vastustest selgus, et osal üliõpilastest oli raskusi emotsionaalsete ja isiklike probleemidega toimetulekul (enda olemusega leppimine) ning samuti oli osa üliõpilaste jaoks keeruline sõnastada omi mõtteid kaasüliõpilastele tagasiside andmisel. Paljud üliõpilased kalduvad olema enda suhtes liiga kriitilised ning seetõttu on väga tähtis suunata neid märkama ning teadvustama enda kui interpreedi ja muusiku positiivseid külgi. Samas näitavad uuringu tulemused, et kavandatud tegevused aitavad üliõpilastel probleemidest üle saada. Tulemustest nähtub, et refleksioonimudeli rakendamisel pilliõppes on palju positiivseid mõjutegureid. Uuringus osalenud üliõpilaste hinnangul võimaldab video näha ennast objektiivsemast vaatenurgast, mis on oluline refleksiooni eeltingimus (vt nt Leijen et al., 2009b; van den Berg, 2001), ning ülesannete täitmine distsiplineerib end süstemaatiliselt arendama (Latukefu, 2009), aitab keskenduda konkreetsetele eesmärkidele ning fookustada harjutamist. Kooskõlas Parncutti (2007) tähelepanekutega võib uuringu tulemuste põhjal väita, et üliõpilased tajusid refleksioonimudeli positiivset mõju pilliharjutamisele: nad õppisid ära tundma ja mõtestama oma nõrku külgi ning jõudma lahendusteni, kuidas neid parandada, mis on kooskõlas pragmatistliku refleksioonikäsitluse eesmärkidega. Veebipõhine tagasiside videole võimaldas kaasata üliõpilastele tagasiside andmisse peale õpetaja 
ka kaasüliõpilasi ning see tugevdas üliõpilaste ühtekuuluvustunnet (Daniel, 2006). Leiti, et kaasüliõpilaste toetav tagasiside aitab kaasa adekvaatse enesehinnangu kujunemisele, mistõttu tunnevad nad end pärast refleksioonitsüklite läbitegemist ka julgemate ja enesekindlamatena. Samuti võetakse kaaslaste parandusettepanekuid ja soovitusi tõsiselt ning rakendatakse neid edaspidisel harjutamisel. Üliõpilaste hinnangute põhjal võib eeldada, et refleksiooni toetamise mudel aitab neil kujuneda ennast juhtivateks õppijateks, kes võtavad oma õppimisprotsessi eest vastutuse (Latukefu, 2009; Zimmerman, 2002). Kõik osalejad leidsid, et sellised ülesanded võiksid olla pilliõppe lahutamatu ja tavapärane osa.

Hiljutises uuringus Eesti üliõpilaste õpikäitumise kohta tuli välja, et valdav osa üliõpilastest eelistab traditsioonilist õpetaja-õpilase suhet, kus õpetaja on autoriteedi rollis ning õpilane ammutab tarkusi, mida õpetaja jagab (Pilli, Sammul, Post, Aasjõe, \& Kruusamäe, 2013), mistõttu võib öelda, et õpiprotsessi reflekteerimine ongi üliõpilaste jaoks keeruline ning esialgu ka võõras. Siiski tuli uuringu põhjal välja, et refleksioonimudeli rakendamine aitas üliõpilastel ennast paremini mõista ning tegevusi mõtestada. Sellest johtuvalt peavad autorid refleksioonimudeli rakendamist ja edasiarendamist väga oluliseks.

Uurimistulemuste põhjal võib järeldada, et videotugi, suunavad küsimused ja kaaslaste tagasiside pakkusid kooskõlas varasemate uurimistulemustega (vt nt Kori et al., 2014; Leijen et al., 2009b; Poom-Valickis \& Mathews, 2013) üliõpilastele olulist tuge. Täpsemalt, eelnimetatud toetuselemendid aitasid üliõpilastel ennast distantsilt jälgida ja hinnata ning seeläbi avastada uusi aspekte enda kui muusiku kohta.

Edasist eritähelepanu vajab aga hindamisülesanne, mille puhul tuleks tagada üliõpilastele vajalike hindamiskriteeriumide kättesaadavus. Õppejõude on vaja kriteeriumide sõnastamisel toetada, sealjuures tuleks normatiivsete kriteeriumide asemel pöörata tähelepanu selliste kriteeriumide formuleerimisele, mis suunaks üliõpilasi oma meisterlikkust hindama (McPherson \& Zimmerman, 2011).

\section{Refleksiooni toetamise mudeli muudatused}

Üliõpilastelt kogutud andmete põhjal tuleks teha mõningaid muudatusi refleksiooni toetamise mudeli rakendamises, et see töötaks tõhusamalt pilliõppe kontekstis. Mudeli täiustamisel tuleks silmas pidada järgmisi aspekte. Esiteks tuleks refleksiooniülesanded siduda põhipilli õppeainega, sest see võiks motiveerida õppejõude hindamiskriteeriumide sõnastamisel ja üliõpilaste toetamisel rohkem pingutama. Teiseks, et luua üliõpilastele võimalus esitada tagasiside saamiseks muusikastiili- või pillispetsiifilisi küsi- 
musi, oleks soovitatav moodustada suhestumisfaasis rühmad, kuhu kuuluks ka sama stiili ja pilli õppivaid tudengeid. Laiapõhjalisema tagasiside andmiseks peaks rühma kuuluma ka teiste pillide ja stiilide esindajaid: nii saab suunata üliõpilasi omandama avaramaid teadmisi muusikast ning valmistada neid ette tööks erinevate koosseisudega ansamblite juhendajatena. Seega oleks mõistlik komplekteerida osalejad võimaluse korral neljaliikmelistesse rühmadesse paarikaupa, ühes rühmas kaks ühe pilli ja/või stiili ning kaks teise pilli ja/või stiili esindajat. Need mõnevõrra vastuolulised soovitused on kooskõlas varasemate tulemustega tantsuõppe uuringust (Leijen et al., 2009b), kus kaasõppijate rolli reflekteerimisel hinnati eri kontekstides erinevalt: reflekteerides tantsutehnika valdamist ja arenguvõimalusi, eelistati selget erialaeksperdi tagasisidet, samas kui koreograafia realiseerumise ja vastukaja puhul hinnati kõrgelt võimalikult erinevate osaliste tagasisidet.

Kuna suurem osa uuringus osalenutest ei järginud soovitust jagada refleksiooniülesanded (kirjeldamine, hindamine ja suhestumine) kolmele nädalale, vaid pidas seda liiga hajutatuks, võiks planeerida kirjeldamis- ja hindamisetapi ühele ning suhestumisetapi teisele nädalale. Et üliõpilased saaksid seda mudelit kasutada ka oma erialase arengu planeerimisel, on soovitatav pikendada mudeli rakendamise aega ning teha refleksioonitsükkel kaks korda õppeaastas, nt sügissemestri alguses ja kevadsemestri lõpus. Pikemale perioodile jagatud tegevused aitavad üliõpilastel paremini oma erialast arengut kavandada, jälgida ja hinnata. Siinse uurimuse tulemuste põhjal võib öelda, et esialgu planeeritud kolme refleksioonitsükli läbimine üheksa nädala jooksul osutus vastupidi mudelit valideerinud ekspertidest õppejõudude arvamusele (Kivestu \& Leijen, 2014) nii lühikese ajavahemiku kohta liiga intensiivseks. Kui esialgse mudeli kavandamisel peeti silmas eeskätt üliõpilaste refleksiooni toetamist ning seetõttu pöörati mõnevõrra vähem tähelepanu planeeritavale ajale, siis praeguse uuringu puhul ilmnes, et üliõpilasi võiksid motiveerida refleksiooniülesanded, mis seostuvad veelgi selgemalt muusikainstrumendi õppimise loogikaga. Nagu ka uuringus osalenud osutasid, ei toimu areng pillimängus nii kiiresti ning erinevate refleksioonietappide käigus endale püstitatud ülesannete ja eesmärkide täitmine võtab esialgses mudelis kajastunust kauem aega. Lisaaja võimaldamine aitab õppija jaoks asjakohaste eesmärkidega realistlikumal viisil tegeleda, mis on nii pragmatistliku refleksioonikäsitluse kui ka konstruktivistliku õpikäsitluse (vt nt Scott, 2011) üks aluspõhimõtteid.

Eeltoodut arvestades võiks refleksioonimudel sisalduda põhipilli õppeaines, kus see toetaks tõhusalt aine eesmärkide ja õpiväljundite saavutamist. Mudeli seostamine otsese õppetööga aitaks tagada õppejõudude toetuse nii hindamiskriteeriumide sõnastamisel kui ka kogu mudeli rakendamisel. 


\begin{tabular}{|c|c|}
\hline 1. refleksioonitsükkel & 2. refleksioonitsükkel \\
\hline 1. nädal & 1. nädal \\
\hline Kirjeldamine & Kirjeldamine \\
\hline Enda pillimängu valitud aspektide & Enda pillimängu valitud aspektide \\
\hline kirjeldamine videosalvestiste toel. & kirjeldamine videosalvestiste toel. \\
\hline Mida ma teen? Mida ma mõtlen? & Mida ma teen? Mida ma mõtlen? \\
\hline Mida ma tunnen? & Mida ma tunnen? \\
\hline Hindamine & Hindamine \\
\hline $\begin{array}{l}\text { Enda pillimängu võrdlemine } \\
\text { etteantud hindamiskriteeriumide } \\
\text { alusel }\end{array}$ & $\begin{array}{l}\text { Enda pillimängu võrdlemine } \\
\text { etteantud hindamiskriteeriumide } \\
\text { alusel }\end{array}$ \\
\hline 2. nädal & 2. nädal \\
\hline Suhestumine & Suhestumine \\
\hline Kaasõppijate ja & Kaasõppijate ja \\
\hline õppejõudude tagasiside & õppejõudude tagasiside \\
\hline 3. nädal & 3. nädal \\
\hline Metarefleksioon & Metarefleksioon \\
\hline $\begin{array}{l}\text { Mida ma eelnevatel nädalatel } \\
\text { reflekteerisin? Milline muusik, } \\
\text { interpreet ma olen? Mis on minu } \\
\text { tugevad küljed? Millega ma pean } \\
\text { tegelema? Millised eesmärgid } \\
\text { püstitan järgnevaks perioodiks? }\end{array}$ & $\begin{array}{l}\text { Mida ma eelnevatel nädalatel } \\
\text { reflekteerisin? Milline muusik, } \\
\text { interpreet ma olen? Mis on minu } \\
\text { tugevad küljed? Millega ma pean } \\
\text { tegelema? Kuidas ma } \\
\text { saavutasin püstitatud eesmärgid? }\end{array}$ \\
\hline
\end{tabular}

Joonis 2. Üliõpilaste refleksiooni toetamise mudel pilliõppes

Uurimistulemuste põhjal täiustatud refleksiooni toetamise mudel võiks koosneda refleksioonifaasist ja metarefleksiooni faasist, kusjuures refleksioonifaas moodustuks omakorda kahest tsüklist (joonis 2), millest esimene korraldatakse sügissemestri alguses (septembris) ja teine kevadsemestri lõpus (mais). Mõlemad tsüklid hõlmaksid kirjeldamis-, hindamis- ja suhestumisülesandeid ning nende protsesside toetamist. Tsüklite kestus oleks kaks nädalat, kusjuures esimesel nädalal täidetaks kirjeldamis- ja hindamisülesandeid ning teisel nädalal suhestumisprotsesside ülesandeid. Mõlema tsükli läbimisele järgneks refleksiooniprotsessi reflekteerimine ehk metarefleksiooni faas. Et mudel töötaks tõhusamalt ka erialase arengu planeerimisel, peaks üliõpilane esimese refleksioonitsükli lõpus püstitama endale ülesanded järgnevaks õppeaastaks ning teise refleksioonitsükli läbimisel kevadel hindama oma eesmärkide saavutamist. 
Kokkuvõtteks võib öelda, et pilliõppe konteksti loodud refleksioonimudel toetab konstruktivistliku õpimeetodi rakendamist. Selle meetodi kohaselt avaldab teadmiste omandamisele suurt mõju suhtlus teistega ning analüüsi, probleemide lahendamise ning küsimustele vastuste otsimise kaudu konstrueeritakse uus teadmine (Webster, 2011). Samuti laiendab uuringus osalenud üliõpilaste hinnangul refleksioonimudeli rakendamine muusikaõppes väga traditsioonilist õpetaja-õpilase suhet ning võimaldab neil ise aktiivselt oma õpinguid ja arengut kavandada ning probleeme lahendada (Scott, 2011).

Edasistes uuringutes on osalejate hinnangute kõrval soovitatav analüüsida ka õppijate refleksiooni ning uurida lähemalt, kuidas mõjutab ülesannete täitmine üliõpilaste refleksiooni kvaliteeti.

\section{Kasutatud kirjandus}

Argyris, C., \& Schön, D. A. (1974). Theory in practice: Increasing professional effectiveness. San Francisco: Jossey-Bass.

Benammar, K. (2004). Conscious action through conscious thinking: Reflection tools in experiential learning. Amsterdam: Openbare les Lectoraat Reflectie.

Biggs, J. (1987). Student approaches to learning and studying. Hawthorn: Australian Council for Educational Research.

Billing, D. (2007). Teaching for transfer of core/key skills in higher education: Cognitive skills. Higher Education, 53(4), 483-516.

http://dx.doi.org/10.1007/s10734-005-5628-5

Brown, J. K. (2008). Student-centered instruction: Involving students in their own education. Music Educators Journal, 94(5), 30-35.

http://dx.doi.org/10.1177/00274321080940050108

Clark, P. G. (2009). Reflecting on reflection in interprofessional education: Implications for theory and practice. Journal of Interprofessional Care, 23(3), 213-223. http://dx.doi.org/10.1080/13561820902877195

Daniel, R. (2006). Exploring music instrument teaching and learning environments: Video analysis as a means of elucidating process and learning outcomes. Music Education Research, 8(2), 191-215. http://dx.doi.org/10.1080/14613800600779519

Dewey, J. (1933). How we think. Buffalo, NY: Prometheus Books.

Draper, P. (2007). Students doing the driving: How undergraduates use ICT to enhance reflective practice, peer review and collaborative learning. In C. Grant (Ed.), Music in Australian tertiary institutions: Issues for the 21st century. Brisbane: Griffith University Press. Retrieved from http://www.nactmus.org.au/NACTMUS2007/index.html.

Gibbs, A. (1997). Focus groups. Social Research Update, 19. Retrieved from http://sru.soc.surrey.ac.uk/SRU19.html. 
Kivestu, T., \& Leijen, Ä. (2014). A model for supporting students' reflection in tertiary music education. Procedia - Social and Behavioural Sciences, 112, 199208. http://dx.doi.org/10.1016/j.sbspro.2014.01.1156

Kori, K., Pedaste, M., Leijen, Ä., \& Mäeots, M. (2014). Supporting reflection in technology-enhanced learning. Educational Research Review, 11, 45-55. http://dx.doi.org/10.1016/j.edurev.2013.11.003

Korthagen, F., \& Vasalos, A. (2005). Levels in reflection: Core reflection as a means to enhance professional growth. Teachers and Teaching: Theory and Practice, 11(1), 47-71. http://dx.doi.org/10.1080/1354060042000337093

Kährik, P., Leijen, Ä., \& Kivestu, T. (2012). Developing music listening skills using active learning methods in secondary education. Procedia - Social and Behavioral Sciences, 45, 206-215. http://dx.doi.org/10.1016/j.sbspro.2012.06.557

Latukefu, L. (2009). Peer learning and reflection: Strategies developed by vocal students in a transforming tertiary setting. International Journal of Music Education, 27(2), 128-142. http://dx.doi.org/10.1177/0255761409102320

Leijen, Ä. (2008). The reflective dancer: ICT support for practical training (Doctoral dissertation). University of Utrecht, Utrecht.

Leijen, Ä., Lam, I., Wildschut, L., \& Simons, P. R.-J. (2009a). Difficulties teachers report about students' reflection: Lessons learned from dance education. Teaching in Higher Education, 14(3), 315-326. http://dx.doi.org/10.1080/13562510902898882

Leijen, Ä., Lam, I., Wildschut, L., Simons, P. R.-J., \& Admiraal, W. (2009b). Streaming video to enhance students' reflection in dance education. Computers \& Education, 52(1), 169-176. http://dx.doi.org/10.1016/j.compedu.2008.07.010

Leijen, Ä., Valtna, K., Leijen, D. A. J., \& Pedaste, M. (2012). How to determine the quality of students' reflections? Studies in Higher Education, 37(2), 203-217. http://dx.doi.org/10.1080/03075079.2010.504814

Mackintosh, C. (1998). Reflection: A flawed strategy for the nursing profession. Nurse Education Today, 18(7), 553-557. http://dx.doi.org/10.1016/S0260-6917(98)80005-1

McPherson, G. E., \& Zimmerman, B. J. (2011). Self-regulation of musical learning: A social cognitive perspective on developing performance skills. In R. Colwell \& P. R. Webster (Eds.), MENC handbook of research on music learning. Volume 2: Applications (pp. 130-175). Oxford: Oxford University Press.

Meijer, P. C. (2013). Kogenud õpetaja praktiline teadmine õpetajakoolituse osana. Eesti Haridusteaduste Ajakiri, 1, 8-24. http://dx.doi.org/10.12697/eha.2013.1.02

Moon, J. A. (2004). Reflection in learning and professional development: Theory and practice. New York: Routledge Falmer.

Mountford, B., \& Rogers, L. (1996). Using individual and group reflection in and on assessment as a tool for effective learning. Journal of Advanced Nursing, 24(6), 1127-1134. http://dx.doi.org/10.1111/j.1365-2648.1996.tb01017.x

Nielsen, S. (2001). Self-regulating learning strategies in instrumental music practice. Music Education Research, 3(2), 155-167. http://dx.doi.org/10.1080/14613800120089223

Parncutt, R. (2007). Can researchers help artists? Music performance research for music students. Music Performance Research, 1(1), 1-25. 
Pilli, E., Sammul, M., Post, P., Aasjõe, Ü., \& Kruusamäe, K. (2013). Eesti kõrgkoolide esmakursuslaste õpi- ja teadmuskäsitus. Eesti Haridusteaduste Ajakiri, 1, 156-191. http://dx.doi.org/10.12697/eha.2013.1.08

Poom-Valickis, K., \& Mathews, S. (2013). Reflecting others and own practice: An analysis of novice teachers' reflection skills. Reflective Practice: International and Multidisciplinary Perspectives, 14(3), 420-434. http://dx.doi.org/10.1080/14623943.2013.767237

Procee, H. (2006). Reflection in education: A. Kantian epistemology. Education Theory, 56(3), 237-253. http://dx.doi.org/10.1111/j.1741-5446.2006.00225.x

Ryan, G., \& Bernard, H. R. (2003). Techniques to identify themes. Field Methods, 15(1), 85-109. http://dx.doi.org/10.1177/1525822X02239569

Schön, D. A. (1983). The reflective practitioner: How professionals think in action. New York: Basic Books, Inc.

Scott, S. J. (2010). A minds-on approach to active learning in general music. General Music Today, 24(1), 19-26. http://dx.doi.org/10.1177/1048371309354432

Scott, S. J. (2011). Contemplating a constructivist stance for active learning within music education. Arts Education Policy Review, 112(4), 191-198. http://dx.doi.org/10.1080/10632913.2011.592469

Sööt, A., \& Leijen, Ä. (2012). Designing support for reflection activities in tertiary dance education. Procedia - Social and Behavioral Sciences, 45, 448-456. http://dx.doi.org/10.1016/j.sbspro.2012.06.581

Zimmerman, B. J. (1998). Academic studying and the development of personal skill: A self-regulatory perspective. Educational Psychologist, 33(2-3), 73-86. http://dx.doi.org/10.1080/00461520.1998.9653292

Zimmerman, B. J. (2002). Becoming a self-regulated learner: An overview. Theory into Practice, 41(2), 64-70. http://dx.doi.org/10.1207/s15430421tip4102_2

Van den Berg, E. (2001). An exploration of the use of multimedia cases as a reflective tool in teacher education. Research in Science Education, 31(2), 245-265. http://dx.doi.org/10.1023/A:1013193111324

Wade, R. C. (1994). Teacher education students' views on class discussion: Implications for fostering critical reflection. Teaching and Teacher Education, 10(2), 231-243. http://dx.doi.org/10.1016/0742-051X(94)90015-9

Webster, P. R. (2011). Construction of music learning. In R. Colwell \& P. R. Webster (Eds.), MENC handbook of research on music learning. Volume 1: Strategies (pp. 35-83). Oxford: Oxford University Press. 


\title{
Supporting music students' reflection in instrument studies
}

\author{
Tuulike Kivestu $^{\text {ac1 }}$, Äli Leijen ${ }^{\text {ab }}$, Kadri Steinbach ${ }^{\text {ac }}$ \\ a University of Tartu, Viljandi Culture Academy \\ ${ }^{b}$ University of Tartu, Institute of Educational Sciencies \\ ${ }^{c}$ Estonian Academy of Music and Theatre
}

\begin{abstract}
Summary
The use of active learning methods is an integral part of contemporary education, including music education (Brown, 2008; Kährik et al., 2012; Scott, 2010, 2011). Active learning in a wider educational context is associated with a constructivist approach. According to constructivism, the acquiring of knowledge is closely connected to communication with others, and, as a result of this, a new cognition is constructed through analysis, solutions to problems and answering questions. Important aspects of this learning process are self-regulation, self-evaluation and reflection of the learning process (Zimmerman, 1998). Such an approach is in contrast with the practice where learner's self-awareness is limited, e.g. learning situations where the students are actively involved in the practical activities, but less attention is paid towards thinking how certain tasks could be solved. Opposing mere practical engagement, it is argued (see e.g. Leijen et al., 2009a; Leijen et al., 2012; Sööt \& Leijen, 2012) that students should be encouraged to reflect on their practice in order to manage, give meaning to, and become aware of their learning.
\end{abstract}

\section{The role of reflection in music education}

The importance of reflection in music education is often referenced in connection with making instrument practice more effective (Parncutt, 2007), as reflecting helps to interpret and explain one's weaknesses and reach conclusions about how to improve upon them. In addition, reflection promotes the emerging of a self-regulated learner who is in charge of their own study process and is able to develop their skills and abilities on their own.

1 University of Tartu, Viljandi Culture Academy, Posti 1, 71004 Viljandi; tuulike.kivestu@ut.ee 
Despite a rise in interest towards active learning methods and selfreflection in the general education community, only limited number of studies are reported in the context of music instrument studies (see e.g., Draper, 2007; Kivestu \& Leijen, 2014). Nielsen (2001) has written about strategies that can be used while learning an instrument. According to Nielsen, music studies often include a self-regulatory aspect but students use them without self-awareness and often in an unsystematic manner.

Reflection and support of it in the context of instrument studies demand more attention and the present research draws on a model that was developed for supporting reflection in this context. The model is based on supporting the four general processes of reflection as proposed by Procee (2006). Experienced lecturers of music education have previously validated the model (see Kivestu \& Leijen, 2014). The present research focuses on the first implementation of the model among students of music instrument studies and attempts to answer the following questions:

1. How do the reflection assignments developed according to the general processes of reflection support the learning process of music students in their perception?

2. How do the music students conceptualize the usefulness of applied reflection tasks for their professional development?

In addition, the suggestions for further development of the model will be proposed based on the answers to the research questions

\section{Method}

\section{Participants}

The model for supporting reflection was applied by 11 students of a music department in an Estonian university, three of these students were studying at the Bachelor level of school music, six in applied higher education of jazz music, and two in applied higher education in traditional music. The participants included five male and six female students between the ages of 19-26. Students had the following specializations: two in saxophone, two in guitar, two in piano, three in voice, one in flute and one in percussion.

\section{Model and data collection}

The model for supporting reflection consists of two phases: reflection and meta-reflection. The reflection phase consists of three cycles in itself description, evaluating and relating (one cycle lasted for 3 weeks). The 
meta-reflection phase (lasting for 2 weeks) consists of reflecting upon the reflection process. The tasks of each cycle are supported by video, different supporting questions and peer feedback.

Regarding the reflection phase, the process of describing demanded the student to make a video of themselves playing their instrument, decide upon two aspects and describe their playing in accordance to those. In the process of evaluation the student was expected to compare their playing to the evaluation criteria provided. In the relation process students were asked to pose two questions they wished to receive feedback on from their peers. Regarding the meta-reflection phase student were asked to look back on the different cycles of reflection phase and think about their professional identity.

A specific course was created in the Moodle environment and a separate topic was created for each task, giving detailed instructions on conducting the task. In addition, for the reflection task the students were divided into groups of four and feedback was given in these groups. The student's field of study or instrument studied was not considered when creating the groups.

Two focus group interviews were carried out to collect data on students' experiences. The first interview was conducted with 5 students, the second with 6 students. Separate questions were asked related to every reflection task, as well as regarding the reflection model in general and possible areas for improvement. Both interviews were recorded and fully transcribed. Data was analysed following the thematic analysis principles.

\section{Main results and discussion}

The results showed that students encounter problems with all processes of reflection and the developed support could facilitate overcoming these problems. More specifically, the participants pointed out that the reflection assignments helped them to take a more objective view on their practice and offered a detailed way for improving in a systematic manner, and helped to focus on specific goals and to target exact training needs as also noted in previous studies (see e.g. Kori et al., 2014; Leijen et al., 2009b). All participants suggested that such reflection assignments should be integrated in regular instrument studies curriculum.

According to the data gathered, certain changes need to be implemented to the organization of the reflection method. This is needed for increasing the meaningfulness of reflection in relation to their music instrument studies. Teacher of the major music instrument should be involved more in this 
process, helping to tie the reflection activities with the studies of the student's main musical instrument. Hopefully this could motivate the university teachers to make more effort for formulating the most useful criteria for evaluation and supporting the students. Another reason is to ensure that the students have the opportunity to propose more specialized questions about style or instrument specifics in order to get more detailed feedback from their teacher and peers who study the me instrument Besides this, there should be also opportunities to receive feedback from students from other areas of specialization because they can point out different aspects. In brief, it would be beneficial if students' groups in the relating phase of reflection would include both students of the same style and instrument as well as different instruments and styles.

Most of the participants of the study did not find it practical to divide the reflection exercises up over the course of three weeks; they thought it was thinly spread. The organization of assignments could be restructured to involve the description and evaluation phases in one week and the relation phase on week two. In order to assure that the students would benefit more from the reflection assignments in relation to their proceedings in the chosen specialization, it is advised to lengthen the timespan of the model and hold a reflective cycle twice a year - for example at the beginning the fall semester and at the end of the spring semester. Assignments divided across a longer time-span would help the students to better plan, monitor and evaluate their professional development. As the participants of the current study noted, growth as a musician does not come fast and requires more time. The latter suggestion is again in line with the idea that reflection assignments need to be meaningful for students and designed to support their own major learning objectives as already proposed by Dewey (1933).

Keywords: reflection, instrument study, constructivism, active learning 